\title{
三次元画像計測による点群データからの パイプラインの変形量の取得
}

\author{
井上 裕貴 1 - 安室 喜弘 2 - 檀 寛成 3 - 小林 晃 4 \\ 1学生 関西大学理工学研究科環境都市工学専攻都市システム工学分野 \\ （干564-8680 大阪府吹田市山手町3丁目3番35号） \\ E-mail:k004627@kansai-u.ac.jp \\ 2正会員 関西大学環境都市工学部都市システム工学科 \\ （干564-8680 大阪府吹田市山手町3丁目3番35号） \\ E-mail:yasumuro@kansai-u.ac.jp \\ 3非会員 関西大学環境都市工学部都市システム工学科 \\ （干564-8680 大阪府吹田市山手町3丁目3番35号） \\ E-mail:dan@kansai-u.ac.jp \\ 4正会員 関西大学環境都市工学部都市システム工学科 \\ （干564-8680 大阪府吹田市山手町3丁目3番35号） \\ E-mail: koba5963@kansai-u.ac.jp
}

\begin{abstract}
近年，構造物の検査や管理において様々な局面で3次元点群計測が取り入れられているが，レーザスキ ヤナが比較的大規模な構造物を対象としており, 点群デー夕を用いた検査手法が確立していない, 狭险な パイプラインの内壁検查への適用には課題がある. 本研究では小型で安価なRGB-Dカメラを用いて, パイ プラインの管内形状を計測しその変形量を算出する技術を提案する. 通常パイプライン管内の断面形状や その変形量はゲージを当てた局所でしか計測しない. 本研究では3次元計測により得られた管内形状の点 群データを直接処理し，点群分布の粗密に関わらず自動的に断面データを抽出し，たわみ量を算出する. $600 \mathrm{~mm} \phi$ のパイプを用いた実験により, 直ちに補修・交換が必要とされる5\%程度のたわみを網羅的に安 定して検出可能であることを確認した。
\end{abstract}

Key Words : pipeline investigation, depth image, RGB-D camera, point cloud, distortion distribution

\section{1. はじめに}

近年様々な分野でレーザスキャナのような光学的な3 次元計測が取り入れられ，非接触で効率的な形状計測の 利点が注目されている.インフラ管理においても，連続 的に点群データを取得することにより密度の高い面的な 3次元情報を取得することができ，またデータの保存・ 再利用が容易に行えるため, トンネルやダム等の構造物 での出来高計算や維持管理に活用されるようになってき た．また車載や空撮用のシステムが発展し，広範囲で長 距離の計測が可能となり，災害現場などの人が立ち入る ことが難しい箇所の現状把握や復旧計画においても3次 元データの取得とその活用が進んでいる（図-1参照）。
広域での活用が進む一方で，筆者らは，小型の3次元計 測機器を用いて, 比較的狭矮なパイプライン管内形状を 計測し，変状を検知するシステムを開発している1)2). 特に地中に埋設されていることが多い水利施設等のパイ

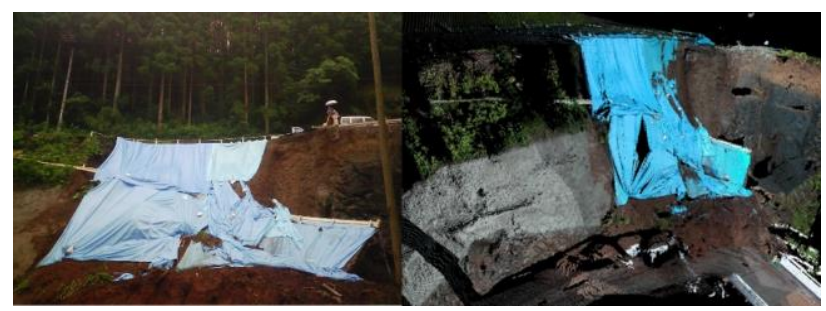

図-1＼cjkstart災害現場イメージと3Dレーザスキャナ観測画像 （3Dレーザスキャナ計測コイシin九州大分） 


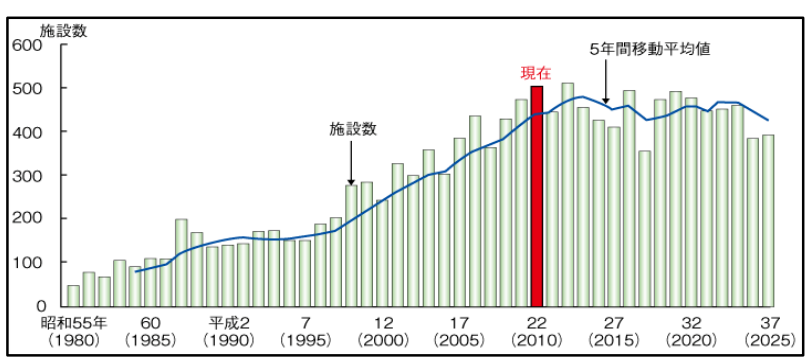

図-2＼cjkstart而用年数を超える施設数 ${ }^{3}$

プラインでは，大型の3次元レーザスキャナでは計測す ることが困難なサイズが多く存在し，その多くは高度経 済成長期に整備されたものが多く，近年それらの耐用年 数とされている40年を超えるものが増加している3) (図2参照）。したがって, 計画的にパイプライン管内の調 査・診断を行い, 問題箇所の把握をすることが急務とさ れている.

\section{2. パイプライン管内の調査方法}

\section{(1) 従来の調査方法}

パイプラインの適切な構造機能を維持するために，管 内の状態を正確に把握することが重要である．現在の調 査方法は，地表面を掘削して行う間接的定量調査と管内 から調査を行う直接的定量調査がある ${ }^{4}$. そのうち，管 内の状態を直接診断する直接的定量調査方法として，デ プスゲージによる入管調査や管内目視による調査, 自走 式ロボットを用いたビデオカメラ調査などがある (図-3 参照）。前者は，断面形状やたわみ量などの劣化と相関 の高い形状的指標を部分的にサンプルする方法である. 後者は，直接人が観測できない状況でも，画像やビデオ として管内表面の性状を連続的に記録できるものである 管内形状の定量的な情報というよりは，調査員による視 認と診断において有効である.

\section{（2）パイプラインの評価基準}

パイプラインの健全度の評価は，管理，埋設条件等を 踏まえて，施設の性能低下に関係する要因とその評価区 分を設定した施設状態評価表を用い，機能診断調査の結

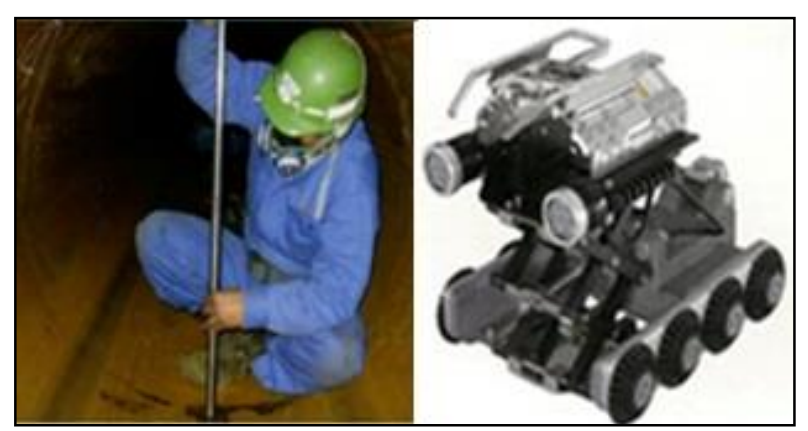

図-3 従来の調査方法
表-1 パイプラインの健全度評価表5)

\begin{tabular}{|c|c|c|c|}
\hline $\begin{array}{l}\text { 健全度 } \\
\text { ランク }\end{array}$ & 施設の状態 & パイプラインにおける現象の例 & $\begin{array}{l}\text { 対虑する } \\
\text { 対策の目安 }\end{array}$ \\
\hline$s-5$ & $\begin{array}{l}\text { 孪状がほとんど認められない } \\
\text { 態。 }\end{array}$ & (1) 新設時点とほぼ同等の状態 & 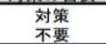 \\
\hline$s-4$ & 軽徽な変状が認められる状態。 & 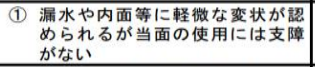 & 要钼察 \\
\hline$s-3$ & 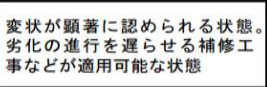 & 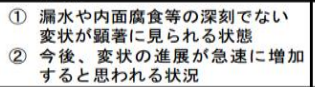 & $\begin{array}{l}\text { 補 修 } \\
\text { (補 强) }\end{array}$ \\
\hline$s-2$ & 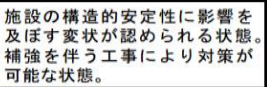 & 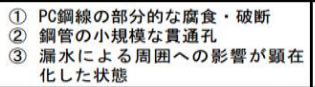 & $\begin{array}{l}\text { 補 強 } \\
\text { (補 修) }\end{array}$ \\
\hline$s-1$ & 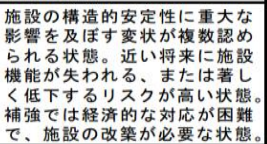 & 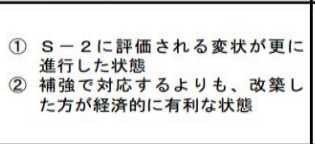 & 改 築 \\
\hline
\end{tabular}

表-2 パイプラインの施設状態評価表 ${ }^{5}$

\begin{tabular}{|c|c|c|c|c|c|c|}
\hline \multicolumn{3}{|c|}{ 許值項目 } & \multicolumn{4}{|c|}{ 㴋酶区分 } \\
\hline & & 健全度ランク & S-5 & s.4 & s-3 & s-2 \\
\hline & \multirow{10}{*}{$\begin{array}{l}\text { 管 } \\
\text { 路 } \\
\text { の } \\
\text { 変 } \\
\text { 状 }\end{array}$} & $\begin{array}{l}\text { Uひ割れ (RC, PC, ACP、 } \\
\text { FRPM) }\end{array}$ & なし & - & あり & - \\
\hline & & $\begin{array}{c}\text { 内面乷装の尜化状況 (SP、 } \\
\text { DCIP) }\end{array}$ & 10\%未满 & - & $10 \%$ 以上 & - \\
\hline & & 発錆状況 (SP、DCIP) & $0.3 \%$ 未満 & 5.0\%未满 & $5.0 \%$ 以上 & - \\
\hline & & $\begin{array}{c}\text { たわみ量(SP, DCIP、PVC、 } \\
\text { FRPM) }\end{array}$ & 3\%未満 & $5 \%$ 未満 & 5\%以上 & - \\
\hline & & 蛇行·沈下 ( $\varphi 700 \mathrm{~mm}$ 未満) & 無 & 管口径の1/2末満 & 管口径の $1 / 2$ 以上 & - \\
\hline & & 蛇行·沈下 ( $9700 \mathrm{~mm}$ 以上) & 無 & 管口径の1/4末満 & 管口径の $1 / 4$ 以上 & - \\
\hline & & $\begin{array}{c}\text { 䋖手曲1゙角度 (RC、PC、ACP、 } \\
\text { FRPM) }\end{array}$ & $\begin{array}{l}\text { 辇容曲げ角度の } \\
1 / 2 \text { 以内 }\end{array}$ & $\begin{array}{l}\text { 䇢容曲|゙ } \\
\text { 角度以内 }\end{array}$ & 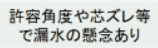 & - \\
\hline & & $\begin{array}{c}\text { 継手間隔 (溶接又は接若綎手は } \\
\text { 除) }\end{array}$ & $\begin{array}{l}\text { 施工管理基準值 } \\
\text { 品 }\end{array}$ & $\begin{array}{l}\text { 規格值外だが止水 } \\
\text { 機能問题なよ }\end{array}$ & $\begin{array}{l}\text { 大幅·全面的に規格 } \\
\text { 值外等て漏水の悬念 } \\
\text { あり }\end{array}$ & - \\
\hline & & 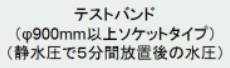 & $80 \%$ より上 & $80 \sim 50 \%$ & 50\%未满 & - \\
\hline & & 進行性 & 有りの場 & 合1ランクダウン(経年 & 変化が見られるもの) & \\
\hline
\end{tabular}

果により行う。施設状態評価表に用いる健全度ランクは， 表-1の健全度評価表を用いる．複数の要因が影響してい る場合には，性能低下を進行させるより支配的な要因に 重点をおいて評価する．施設状態の適切な評価のために は，各施設や地域の条件等を加味することが必要となる. 基本的な評価項目と評価区分を表-2に示す．本研究では， たわみ量の調査に着目する. 現在では，人が管内に入り， デプスゲージなどの機器を用いて調査する必要があるた め，局所的にしか計測できず，時間も要する．従来の画 像検査技術と併せて，管内の情報を連続的に3次元形状 も取得し変形量の観点で性急な対応が必要となる箇所が 見つかれば直ちに，その位置を記録することが有効であ ると考える.ここで, 性急な対応が必要なたわみ量とし ては，健全度ランクS-3に相当する $5 \%$ 程度となる.

\section{3. 先行研究}

\section{（1）先行研究(1)}

パイプラインの内壁計測について，Yasumuroら ${ }^{1)}$ Newcombeらの手法)を適用したRGB-Dカメラを使った 管内測定の提案を行い，実際に $\Phi 1,000 \mathrm{~mm}$ 模型管内を 計測し, 実時間で3次元形状情報を取得する実験を行っ ている. RGB-Dカメラとは, 通常のカラー・カメラとは 別に, 物体の3次元座標を画素単位に測定出来る赤外線 
投影方式の奥行きカメラが搭載されている物である. こ れを用い，1視点からの撮影によって取得したデータを $\mathrm{PC}$ 上で3Dモデルとして可視化し(図-4参照)，0.015mの測 定分解能で, 立体的な変形やたわみ量, 異物の検出に有 効であることを確認している.

\section{(2) 先行研究(2)}

さらに，筆者らは，パイプライン内を進行するRGB-D カメラで管内形状を連続的に計測する方法を提案してい る2). 複数の異なる色のレーザー光源を用いて, 能動的 に複数の輝点マーカをパイプの内壁に付与し, 交互にカ メラとともに前進させて輝点マーカが写りこんだ色情報 つきの形状データを取得している．輝点マーカが一致す るように座標変換を行うことで撮像データ同士が結合さ れ(図-5参照), カメラの撮像位置も特定される. 管内に 特徵が無く, カメラに捉えた情報だけでは移動量が不明 な場合にも，その位置が正しく記録され，連続的にパイ プ内の形状が取得できる機能が実現可能であることが確 認されている. 一方，カメラを使った管内検査において は，高解像度の色情報が主たる判断材料であり，さらに RGB-Dカメラを併用することで，変形量に結びつく形状 情報が得られる。しかし，1視点で得られる3次元点群形 状は, 計測器の画角の制約から, パイプ状の形を成して いない場合がある．複数視点でのデータを統合すれば包 括的なパイプ形状が得られるものの，粗密が不均一な点 群で形状データが構成され，特に断面形状を解析する上 での断面の取り方などに，データの性状が影響すること がある．特に点群の一部のみで円筒形状を当てはめたり 7), 点群の分布に対する固有ベクトルを利用する方法で は, 変状を含む不均一な点群データからパイプの軸方向 を正確に推定するのは難しいケースがある.

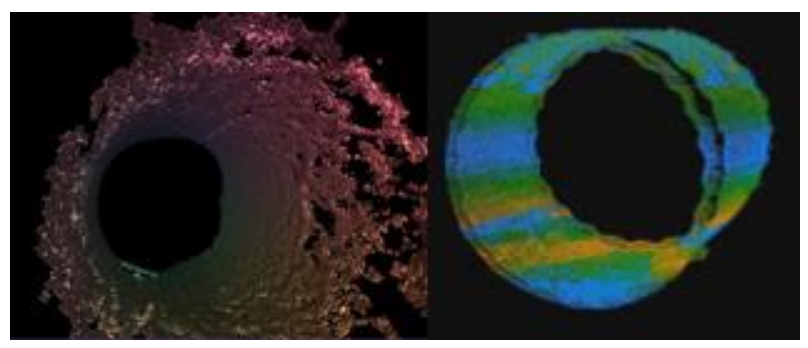

図-4 PC上に3Dモデルとして可視化した様子 ${ }^{11}$

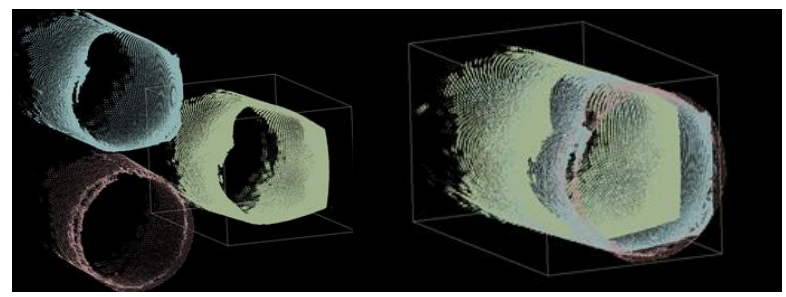

図-5 撮像データの結合2)

\section{4. 提案手法}

\section{(1) 提案手法の概要}

本研究では, 先行研究の枠組みを踏まえ, RGB-D力メ ラで取得したパイプライン管内形状の点群データを解析 し，点群の粗密や分布形状に影響されずに，断面での変 形量の求める手法を提案する. 基本的には，図-6に示す ように取得した3次元点群の各点での法線ベクトルを求 め，それらと垂直に交わるべクトルをパイプ形状の軸方 向ベクトルとする. 軸方向上で任意に断面を取り，その 各断面で変形量を算出する. 以下に手順の詳細を示す.

1. RGB-Dカメラを用いて，パイプライン管内の形状 情報を3次元点群およびメッシュとして取得する.

2. メッシュ情報から各点の法線ベクトルを求める.

3. 各点の法線ベクトルと垂直に交わるべクトルを, パイプラインの軸方向ベクトルとして算出する.

4. 軸方向ベクトルに沿ってパイプラインを細分割し, 任意断面を取得する.

5. 各断面において, あらゆる方向について縦横比を 求め, パイプライン全体の変形量を求める.

6. 求めた変形量によって色分けし, 可視化する.

\section{（3）点群法線ベクトルからの軸方向の算出}

以下に示す方法を用いて各点の法線ベクトルから，円 筒の軸方向の方向ベクトルを求める. 各点におけるパイ プ内壁の法線ベクトルをつぎのように表す.

$$
n_{i}=\left(\begin{array}{l}
x_{i} \\
y_{i} \\
z_{i}
\end{array}\right)(i=1,2, \cdots, k)
$$

行列 $\mathrm{N}$ を次のように定義する.

$$
\mathrm{N}=\left(\begin{array}{c}
n_{1}^{T} \\
\vdots \\
n_{k}^{T}
\end{array}\right)(k \times 3 \text { 行列 })
$$

$n_{i}(i=1,2, \cdots, k)$ のいずれにも直交するべクトル $v$ を求 める軸方向とする.

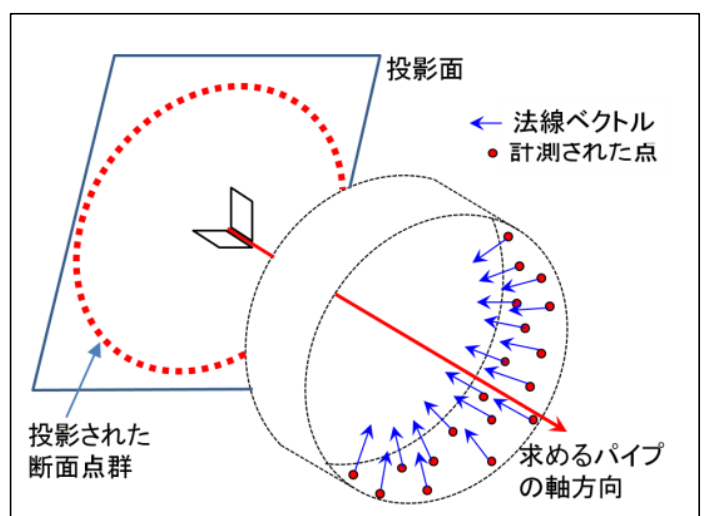

図-6 軸方向と計測点との関係 


$$
v=\left(\begin{array}{l}
\bar{x} \\
\bar{y} \\
\bar{z}
\end{array}\right)
$$

理想的な状況下では $\mathrm{N} v=0$ となるように $v$ を定められ るが，実際は計測ノイズや物理的な変形などにより，そ のような $v$ は存在しないため, 次の誤差 2 乗和を最小化 する解として求める.

$$
\begin{gathered}
\underset{v}{\operatorname{argmin}} \frac{1}{2}\|N v\|^{2}=\frac{1}{2} v^{T} N^{T} N v=\frac{1}{2} v^{T} M v \\
\mathrm{M}=N^{T} N(3 \times 3 \text { 行列 })
\end{gathered}
$$

ただし，vについて制約がないと解が $v=0$ となるため, $v$ について制約が必要である. 本稿では，要素のひと つについて $\bar{z}=1$ (非ゼロ) という簡単な制約を用いる こととする.これにより， $\bar{Z}=0$ であるような真の解 は最適解として得られないこととなるが，そのようなケ 一スが厳密に起きることは考え難く，また，座標系の取 り方を選ぶことにより，回避することは容易に可能であ る.したがって，(4)式は，(5)式のように書くことがで きる.

$$
\begin{aligned}
& \underset{\bar{x}, \bar{y}}{\operatorname{argmin}} f(\bar{x}, \bar{y})=\frac{1}{2}\left(\begin{array}{l}
\bar{x} \\
\bar{y} \\
1
\end{array}\right)^{T}\left(\begin{array}{lll}
m_{11} & m_{12} & m_{13} \\
m_{12} & m_{22} & m_{23} \\
m_{13} & m_{23} & m_{33}
\end{array}\right)\left(\begin{array}{l}
\bar{x} \\
\bar{y} \\
1
\end{array}\right) \\
& =\frac{1}{2}\left(\begin{array}{l}
\bar{x} \\
\bar{y}
\end{array}\right)^{T}\left(\begin{array}{ll}
m_{11} & m_{12} \\
m_{12} & m_{22}
\end{array}\right)\left(\begin{array}{l}
\bar{x} \\
\bar{y}
\end{array}\right)+\left(\begin{array}{l}
m_{13} \\
m_{23}
\end{array}\right)^{T}\left(\begin{array}{l}
\bar{x} \\
\bar{y}
\end{array}\right)+\frac{1}{2} m_{33} \quad(5) \\
& \text { よって, } f(\bar{x}, \bar{y}) \text { の微分D } f(\bar{x}, \bar{y}) \text { が } 0 \text { となるような }(\bar{x}, \bar{y}) \\
& \text { を求めればよい. }
\end{aligned}
$$

$$
\begin{aligned}
\mathrm{D} f(\bar{x}, \bar{y}) & =\left(\begin{array}{ll}
m_{11} & m_{12} \\
m_{12} & m_{22}
\end{array}\right)\left(\begin{array}{l}
\bar{x} \\
\bar{y}
\end{array}\right)+\left(\begin{array}{l}
m_{13} \\
m_{23}
\end{array}\right)=0 \\
\left(\begin{array}{l}
\bar{x} \\
\bar{y}
\end{array}\right) & =-\left(\begin{array}{ll}
m_{11} & m_{12} \\
m_{12} & m_{22}
\end{array}\right)^{-1}\left(\begin{array}{l}
m_{13} \\
m_{23}
\end{array}\right)
\end{aligned}
$$

この時 $(\bar{x}, \bar{y}, 1)^{T}$ が誤差2乗和を最小にし, 求める軸方向 の方向ベクトル $v$ となる.

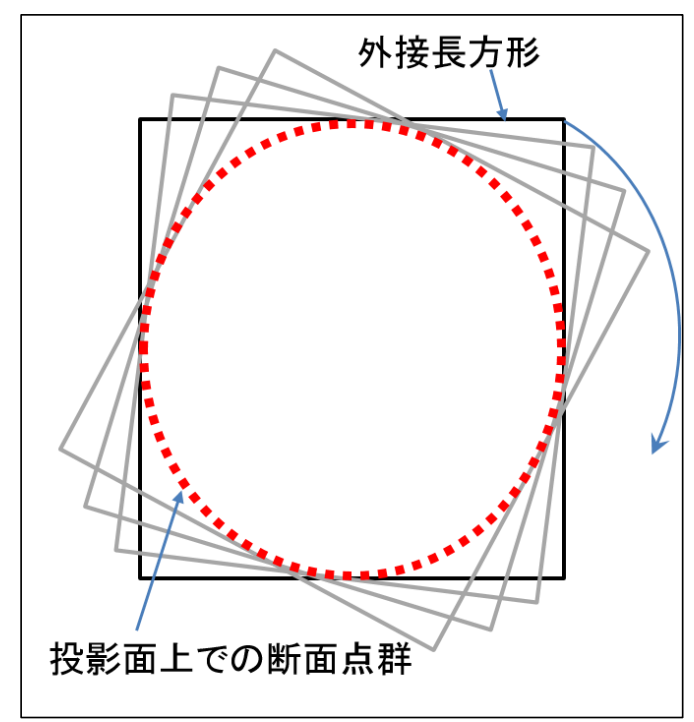

図-7 変形量の求め方

\section{（4） 法線ベクトルからの軸方向の算出}

前節でパイプの軸方向ベクトルを求めることにより, それを法線とする任意の平面が定義でき，この平面がパ イプ形状の垂直断面となる．図-7に示すように，軸方向 ベクトル上で薄くスライスして取り出した点群をこの断 面上に投影することで，3次元点群のパイプ形状データ に対して，任意の垂直断面形状が得られる。たわみ量は， 基本的にこの断面形状の縦横比である.ここでは外接長 方形を各点ごとに設定することで，あらゆる方向におけ るたわみを精査し，もつとも変形が大きい方向を特定す ることができる.

\section{5. 実験}

\section{(1) 実験概要}

提案手法に従って，RGB-Dカメラを用いて形状情報を 取得し変形量を求める. また変形量を求めた後，その変 形量によって点群を色分けし可視化する. 管内のカラー 情報と形状情報を取得するRGB-Dカメラとして，XBOX 360用Kinect (Microsoft 社)を使用する. KinectはRGB力ラ 一・カメラに加え, 物体の三次元画像を画素単位に測定 できる赤外線投影方式の奥行きカメラが搭載されている. その仕様を表-3に示す. 形状情報取得ソフトウェアは

Artec Studio (データ・デザイン社)を使用する．Artec Studio はリアルタイムで3次元形状情報を取得でき，メッシュ 情報と色情報も取得しているためテクスチャマッピング されたポリゴンモデルを作成できる，取得したデータか らの軸方向ベクトルの算出には, 数值解析用フリーソフ トウェアOctaveを使用した．測定対象物としては， $\Phi$ $600 \mathrm{~mm} \times 2,000 \mathrm{~mm}$ のボイド管を使用した。これは中程度 のサイズであるが，屋外用レーザスキャナでの計測は難

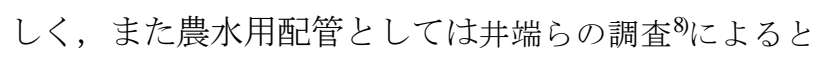
事故率が高いという報告がある.

\section{(3) 実験手順}

管内に異常がない状態と異常がある状態を想定して計 測対象を用意し，変状を模して内部に板を据えた（図-8 参照）。Kinectを用いて管内形状の3次元形状情報と色情 報を取得する（それぞれ，点数270万，320万，メッシュ 数500万，590万）. 取得したデータは3次元モデル編集 ソフトウェア（Meshlab）を使用して，ノイズ除去を行 い，点群のみのデータとする（それぞれ，点数5万，5 万）.ノイズ除去を行ったデータから方向ベクトルを求 め, その方向に円筒を約 $10 \mathrm{~cm}$ 幅に分割し, 断面形状を 取得し，たわみ量を求める. 
表-3 RGB-DカメラKinect (Microsoft社)の仕様

\begin{tabular}{|l|c|}
\hline Device & Kinect $^{T M_{\text {for Xbox360 }}}$ \\
\hline Field of view & $57^{\circ}(\mathrm{H}) \times 43^{\circ}(\mathrm{V})$ \\
\hline Depth image size & 640 pix $(\mathrm{W}) \times 480 \mathrm{pix}(\mathrm{H})$ \\
\hline Depth range & $0.8 \sim 4.0 \mathrm{~m}$ \\
\hline Frame rate & $30 \mathrm{fps}$ \\
\hline
\end{tabular}

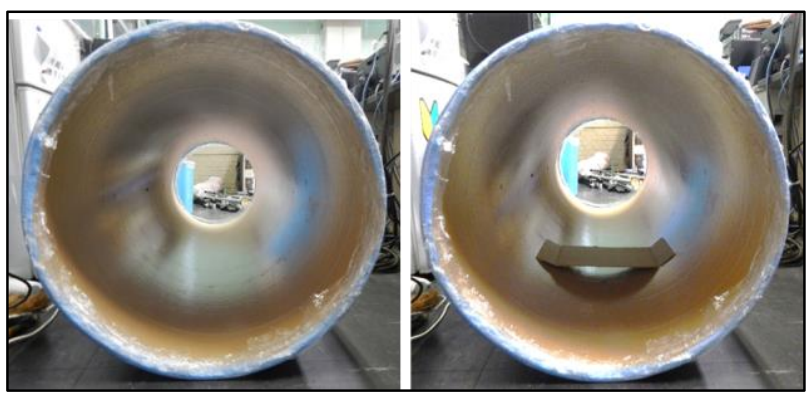

図-8 変状のない状態 (左) と変状がある状態 (右)

\section{(4) 実験結果}

Kinectで撮影したデータと各点の法線を表示したデー 夕を図-9に示す. 図-9右側データの青色の線の一本一本 が法線ベクトルを表している. この法線ベクトルをもと にパイプの方向ベクトルを求める. 図-10のようにパイ プが壁と床に接するように設置し，パイプの軸方向ベク トルの参照基準とした. 提案手法により算出されたパイ プの軸方向ベクトルは，壁面と床面の法線方向とそれぞ れ0.26度以下の誤差で垂直をなしていることが確認でき た. 次に，断面を切り取り可視化し，その断面の1点に 着目して外接長方形を描いたものを図-11に示す.これ をこの断面上の全ての点で行い，各点における外接長方 形の縦横比の值を表した物を図-12に示す。図-12は各点 における横の長さ/縦の長さになっており1に近いほど変 形量が少ないことを表している. 図-12の横軸の矢印と 図-11の矢印は同一点の位置に対応しており，図-12の横 軸の角度は矢印の点から反時計回りの順になっている. またパイプラインを3Dモデルとして可視化し，先ほど の縦横比をもとに各点を色付けしたものを図-13に示す. この図では，直ちに補修が必要とされる5\%の変形量に 未たない箇所は緑色，5\%以上圧縮変形をしている（図一 12の縦軸の值が 0.95 以下）箇所が青色，5\%以上膨張変形 している（図-12の縦軸の值が1.05以上）が赤色になって いる. ただし変形量として縦横比を使用しているため, 圧縮変形と膨張変形は互いに直角方向に現れる. 実際の 圧縮変形量，膨張変形量は，管径における規定值と実測 值との比較により参照できる. また今回の実験で想定し た変状は $\Phi 600 \mathrm{~mm}$ に対して，内壁が内側に最大 $50 \mathrm{~mm}$ 変 形していることに相当し，その箇所での縦横比は約 0.916となる.今回の実験結果でも最も変形が起きてい る方向での縦横比の值が約 0.912 となっており，1\%程度 の誤差で変形が検出可能であることが確認できた.

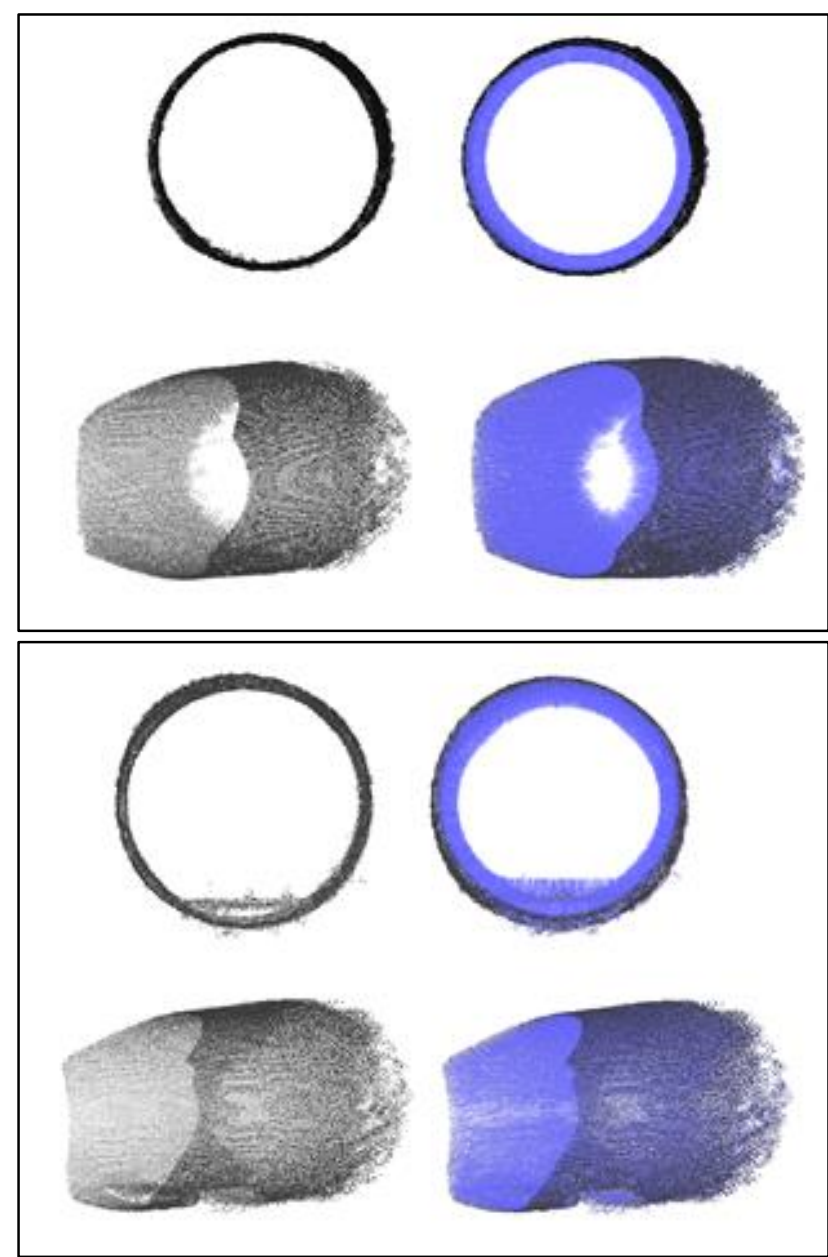

図-9 kinectで撮影したデータと法線を表示したデータ

異常なし（上）異常あり（下）

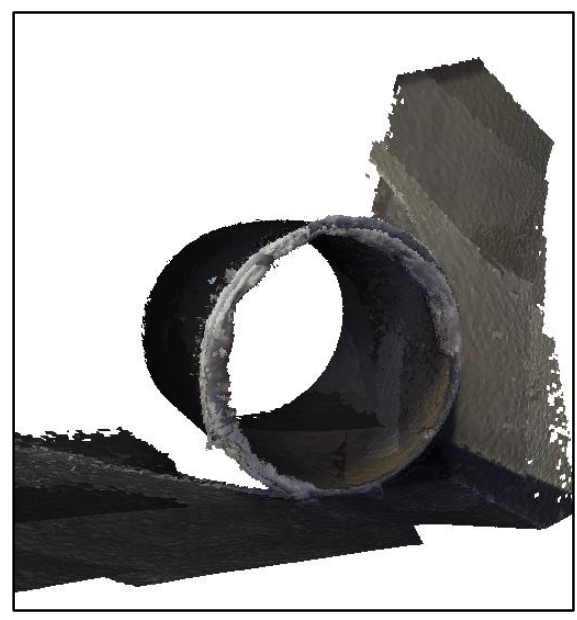

図-10 壁と床とパイプの位置関係

\section{(5) 考察}

従来，RGB-Dカメラによる形状計測をパイプライン構 造物の損傷検証に利用した例は少なく, 今回, 形状フィ ッティングではなく，法線ベクトルによる幾何情報に注 目した点が奏功していると考えられる．直線部だけでは あるが，仮想的には，管内のあらゆる位置と方向に対し 
てひずタゲージを当てて検査していることに相当する効 果が期待できる. 今後の課題としては，大規模に得られ た形状データに提案手法を適用して効果を確認すること が挙げられる。

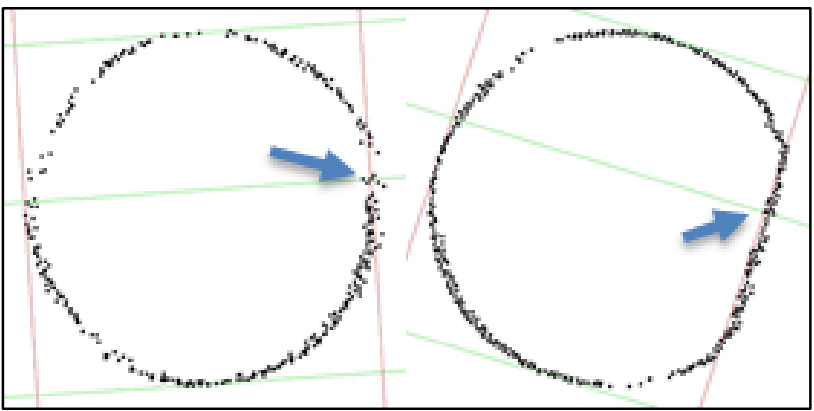

図-11 断面 形状を求め外接長方形を描画
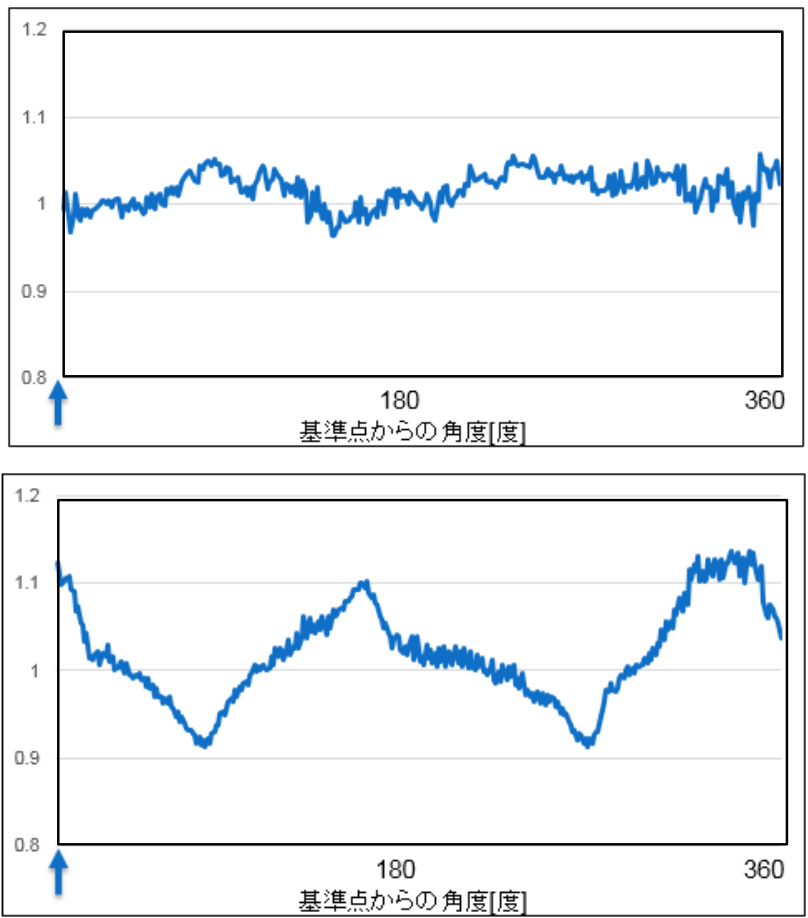

図-12 各点における縦横比のグラフ

（上）が異常なし（下）が異常あり

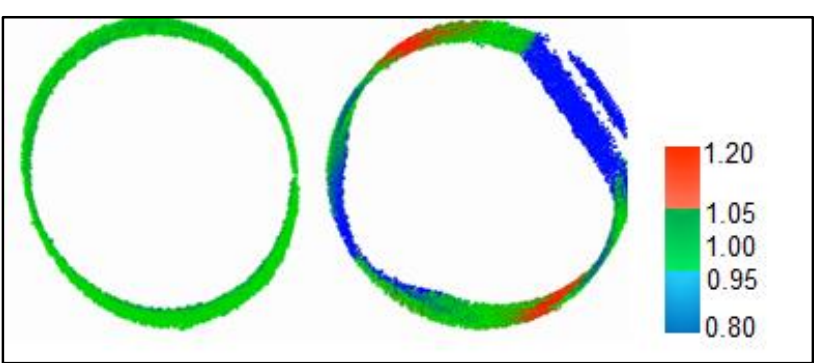

図-13＼cjkstart変形量による色分け

\section{6. おわりに}

本研究では，小型の3次元計測機器を用いてパイプラ インの管内形状を取得し，従来のパイプライン調査では 難しいとされていたたわみ量や断面形状の測定において, 3次元点群情報を利用寸る方法を提案した．そしてkinect を用いた実装と，円筒形模型を使用した実験により，任 意の直線部におけるパイプにおいて修復が必要とされる たわみ量の検出において，計測点群の分布や変形方向に 影響されずに，正確な断面の抽出と最大たわみ量の測定 が可能であることを確認した。

謝辞：本研究の一部は独立行政法人日本学術振興会 科 学研究費補助金（15H02983）の助成による.

(2015. 10.26受付)

\section{参考文献}

1) Yoshihiro Yasumuro, Arata Nagakusa, Hiroshige Dan, Akira Kobayashi, : Inner Surface Measurement with RGB-D Camera for Pipeline Asessment, Proceedings of the First International Conference on Civil and Building Engineering Informatics(ICCBEI2013), pp.87-89, 2013.

2) 井上裕貴他: パイプライン管内形状の連続的な三次元画 像形状計測手法，土木学会論文集F3，70(2), I_243-I_248, 2014.

3）農林水産省 : 農業生産を支える農地、資金、研究・技術 開発、関連団体をめぐる状況.

<http://www.maff.go.jp/j/wpaper/w_maff/h22_h/trend/part1/chap2/c7_0 1_06.html>（入手2014.12.17)

4) No-Dig-Today 管路内部からの調査・探査・診技術，日本 非開削技術協会誌, No67, pp.5-9, 2009.

5) 農村振興局：農業水利施設の機能保全の手引き「パ イプライン」, pp.1-62, 2008.

$<$ http://www.maff.go.jp/j/nousin/mizu/sutomane/pdf/pipe01.pdf > (入手 2014.10.27)

6) Richard A. Newcombe, et al : KinectFusion: Real-Time Dense Surface Mapping and Tracking, in IEEE ISMAR, IEEE, pp.1-8, 2011.

7) Kazuaki Kawashima, Satoshi Kanai and Hiroaki Date : As-built modeling of piping system from terrestrial laser-scanned point clouds using normal-based region growing, , Journal of Computational Design and Engineering, Vol. 1, pp.13-26, 2014.

8) 井端 洸, 西山 龍: 農業用パイプラインの事故要 因分析一調査対象拡充と新たな傾向一, 農業農村工 学会大会講演会講演要旨集,pp. 738-739, 2014. 


\title{
DEFLECTION COMPUTATION OF PIPELINE SURFACE BASED ON 3D POINT CLOUD FROM DEPTH CAMERA
}

Hiroki Inoue, Yoshihiro Yasumuro, Hiroshige Dan, Akira Kobayashi

\begin{abstract}
Numerous developed countries are currently facing problems resulting from the aging of decades-old infra-structures built during periods of rapid economic growth. Additionally, under prevailing severe fiscal circumstances found in many aging societies, it is not realistic to deal with every failing infrastructure facility in every part of a country. This paper focuses on pipelines for water supply, sewerage, and agricultural water use, many of which are buried, which makes investigating their distortion and deterioration difficult without excavation. Under such conditions, maintenance work proceeds slowly and failing buried pipes eventually rupture, which frequently inconvenience citizens and damage property. The authors have been proposing an investigation system that utilizes an RGB-D camera, or a depth-imaging device to examine pipeline interiors. RGB-D cameras can collect not only the RGB-color imagery, but also three-dimensional (3D) depth information from pipe interiors. Taking advantage of the compact size of RGB-D cameras, our proposed concept is based on the construction of a self-propelled robot system that will scan pipeline interiors insitu, thus providing a means of conducting fast and inexpensive investigations that do not require large-scale excavations. This paper describes a novel method that can be used to detect deflection in pipe-shaped structures directly based on depth image capturing with a RGB-D camera. In order to settle intersection planes for deflection examination, the key idea is to find the longitudinal direction from the captured depth images based on the normal vector information, even in the cases that captured 3D point distribution does not form an entire piped-shape. This paper also shows that, based on a prototype implementation using a Kinect camera, the proposed method shows effective performances for actual point cloud data with light computational costs.
\end{abstract}

